\title{
ON THE OCCASION OF SIR LUDWIG'S 80th BIRTHDAY
}

\author{
JoHN S. Young, M.D. \\ Director, National Spinal Cord Injury Data Research Center, \\ Good Samaritan Hospital, II 30 East McDowell Road, Phoenix, \\ Arizona 85006, U.S.A.
}

RARELY in a lifetime, do you meet a unique individual such as Sir Ludwig Guttmann. The circumstances of my first encounter with Sir Ludwig are almost as memorable as the initial introduction to the special lady who became my wife. Time has not faded the memory of either experience.

My first meeting with Sir Ludwig occurred in 1963 at Stoke Mandeville Hospital. Since no one had told me that Stoke Mandeville Hospital was not at Stoke Mandeville, I naturally got off the train at that station and then walked the several miles to the hospital lugging my 40-pound suitcase. I arrived, unannounced, in time to join Sir Ludwig during his clinical rounds.

Here was THE man, short of stature, but positively vibrating with energy. He was entering a ward with his entourage of registrars, nurses, therapists, and whoever, strung out behind him like a bevy of quail. Awaiting in the ward were the patients. They were sitting straight in their wheelchairs, lined up in meticulous order. I glanced at the few patients confined to their beds. 'My God', I thought, 'they are lying at attention. "Files-on-Parade". Where is Danny Deever ?'

'The man is a martinet', I said to myself. 'He belongs on the drill field, not in a hospital ward.'

My initial erroneous impression was quickly corrected. As he passed from patient to patient, Sir Ludwig displayed the qualities of a great physician. His rapport with his patients was a beauty to behold. He knew their medical situation in detail. He knew their names, their families, their concerns. His instructions to his staff were crisp, and clear; interspersed with short mini-lectures on specific points of medical interest. Here was Sir Ludwig, the teacher. Danny Deever turned out to be a miserable registrar who had failed to do a proper neurological examination on a newly admitted patient. I'm sure he would have preferred hanging. Apparently, Sir Ludwig demanded excellence from his staff as well as from himself.

Later in the morning Sir Ludwig, generously and graciously, took me-an unexpected, unknown stranger-to his office. We leisurely discussed the philosophy of spinal cord injury care. I mostly listened. Here was the prophet-the visionary-the leader. He had espoused the cause of spinal man with a missionary zeal equal to the intellectual and professional skills I had observed during his clinical rounds earlier in the day.

Over the years, subsequent to that initial meeting, I have been privileged to meet with Sir Ludwig on numerous occasions. We have shared a common cause. His writings and teachings have permeated into concepts of spinal cord injured care in the United States.

In I973, a joint Conference of the International Medical Society of Paraplegia and the Veteran's Administration on the management of spinal cord injury was held in Phoenix, Arizona. The Conference was dedicated to Sir Ludwig Gutt- 
mann. The United States, along with all countries, owe much to his intellect, vision and perseverance.

Sir Ludwig has given us many things. He established the International Society of Paraplegia. He was the leader in developing a programme of International wheelchair sports. He developed and refined techniques of diagnosis and treatment. In my mind, his greatest contribution has been his living demonstration that the proper treatment of spinal man demands spinal cord injury centres offering specialised care. The fact that thousands upon thousands of paralysed persons throughout the world are living healthy and successful lives is, in large measure, a testimonial to the wisdom and leadership of this great physician. 